\title{
Substituent effect on the energy barrier for $\sigma$-bond formation from $\pi$-single-bonded species, singlet 2,2-dialkoxycyclopentane-1,3-diyls
}

\author{
Jianhuai $\mathrm{Ye}^{1}$, Yoshihisa Fujiwara ${ }^{2}$ and Manabu Abe ${ }^{* 1,3}$
}

\section{Full Research Paper}

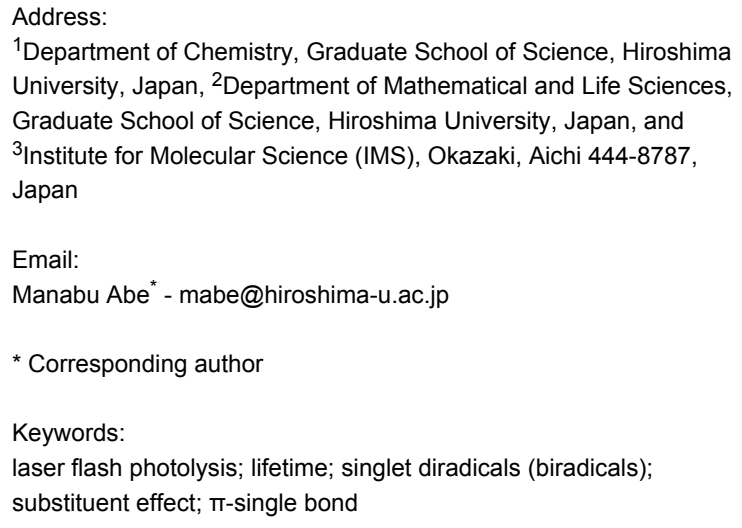

${ }^{1}$ Department of Chemistry, Graduate School of Science, Hiroshima University, Japan, ${ }^{2}$ Department of Mathematical and Life Sciences, Graduate School of Science, Hiroshima University, Japan, and ${ }^{3}$ Institute for Molecular Science (IMS), Okazaki, Aichi 444-8787, Japan

Email:

Manabu Abe* - mabe@hiroshima-u.ac.jp

* Corresponding author

Keywords:

laser flash photolysis; lifetime; singlet diradicals (biradicals); substituent effect; $\pi$-single bond

Beilstein J. Org. Chem. 2013, 9, 925-933.

doi:10.3762/bjoc.9.106

Received: 14 March 2013

Accepted: 22 April 2013

Published: 14 May 2013

This article is part of the Thematic Series "New reactive intermediates in organic chemistry".

Guest Editor: G. Bucher

(C) 2013 Ye et al; licensee Beilstein-Institut. License and terms: see end of document.

\begin{abstract}
Background: Localized singlet diradicals are in general quite short-lived intermediates in processes involving homolytic bondcleavage and formation reactions. In the past decade, long-lived singlet diradicals have been reported in cyclic systems such as cyclobutane-1,3-diyls and cyclopentane-1,3-diyls. Experimental investigation of the chemistry of singlet diradicals has become possible. The present study explores the substituents and the effect of their substitution pattern at the $\mathrm{C}(1)-\mathrm{C}(3)$ positions on the lifetime of singlet octahydropentalene-1,3-diyls to understand the role of the substituents on the reactivity of the localized singlet diradicals.
\end{abstract}

Results: A series of singlet 2,2-dialkoxy-1,3-diaryloctahydropentalene-1,3-diyls DR were generated in the photochemical denitrogenation of the corresponding azoalkanes AZ. The ring-closed products CP, i.e., 3,3-dialkoxy-2,4-diphenyltricyclo[3.3.0. $\left.0^{2,4}\right]$ octanes, were quantitatively obtained in the denitrogenation reaction. The first-order decay process $(k=1 / \tau)$ was observed for the fate of the singlet diradicals $\mathbf{D R}\left(\lambda_{\max } \approx 580-590 \mathrm{~nm}\right)$. The activation parameters, $\Delta H^{\star}$ and $\Delta S^{\ddagger}$, for the ringclosing reaction ( $\sigma$-bond formation process) were determined by the temperature-dependent change of the lifetime. The energy barrier was found to be largely dependent upon the substituents Ar and Ar'. The singlet diradical DRf (Ar = 3,5-dimethoxyphenyl, $\mathrm{OCH}_{2} \mathrm{Ar}$ ' $=\mathrm{OCH}_{2}$ (3,5-dimethoxyphenyl)) was the longest-lived, $\tau_{293}=5394 \pm 59 \mathrm{~ns}$, among the diradicals studied here. The lifetime of the parent diradical DR $\left(\mathrm{Ar}=\mathrm{Ph}, \mathrm{OCH}_{2} \mathrm{Ar}{ }^{\prime}=\mathrm{OCH}_{3}\right)$ was $299 \pm 2 \mathrm{~ns}$ at $293 \mathrm{~K}$.

Conclusion: The lifetimes of the singlet 1,3-diyls are found to be largely dependent on the substituent pattern of Ar and Ar' at the $\mathrm{C}(1)-\mathrm{C}(3)$ positions. Both the enthalpy and entropy effect were found to play crucial roles in increasing the lifetime. 


\section{Introduction}

Localized singlet diradicals are key intermediates in processes involving the homolytic bond-cleavage and formation reactions (Figure 1) [1,2]. The singlet diradicals are, in general, quite short-lived species due to the very fast radical-radical coupling reaction [3]. However, in the past decade, the singlet diradicals have been observed or even isolated in cyclic systems such as cyclobutane-1,3-diyls [4-20] and cyclopentane-1,3-diyls [17,2126]. Detailed experimental study of singlet diradical chemistry is thus now possible using the long-lived localized singlet diradicals.

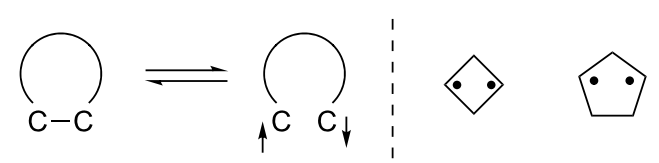

Figure 1: Localized singlet diradicals.

So far, we have studied singlet diradical chemistry using longlived 2,2-dialkoxy-1,3-diphenyloctahydropentalene-1,3-diyls DR with a singlet ground state, which can be cleanly generated by the photochemical denitrogenation of the corresponding azoalkanes AZ (Scheme 1). The 2,2-electron-withdrawinggroup-substituted singlet 1,3-diradicals are categorized as Type-1 diradicals [1,27], which possess a $\pi$-single-bonding character $(-\pi-$, closed-shell character) between the two radical sites. The role of the alkoxy group (OR) on the lifetime $(k=1 / \tau)$ was investigated by combined studies of experiments and quantum chemical calculations [26,28]. The steric repulsion between the alkoxy group and the phenyl ring, which is indicated in the transition-state structure for the ring-closing reaction (Scheme 1), was found to play an important role in determining the energy barrier of the ring-closing process, $\tau_{293}=292 \mathrm{~ns}\left(\right.$ DRa: $\left.\mathrm{OR}=\mathrm{OCH}_{3}, \lambda_{\max }=574 \mathrm{~nm}\right)$ and $2146 \mathrm{~ns}$ (DRb: OR $=\mathrm{OC}_{10} \mathrm{H}_{21}, \lambda_{\max }=572 \mathrm{~nm}$ ) [26]. The study prompted us to further investigate the kinetic stabilization of the singlet diradical species.

In the present study, the effect of the bulky 3,5-dimethoxyphenyl group substituent was investigated on the lifetime of the localized singlet diradicals. Thus, the aryl substituent was introduced at $\mathrm{C}(1), \mathrm{C}(2)$, or/and $\mathrm{C}(3)$ positions of the diradicals DRd-g, and the substituent effects on the lifetime of the singlet diradicals were compared with the lifetime of a phenyl-groupsubstituted diradical DRc and the parent diradical DRa. The laser flash photolysis technique was used for the generation of DRc-g from the corresponding azoalkanes AZc-g (Scheme 2).

\section{Results and Discussion}

Synthesis of AZc-g and their steady-state photolyses. The precursor azoalkanes $\mathbf{A Z c}-\mathbf{g}$ were prepared in an analogous method to the synthesis of AZa,b [28] (Scheme 3). Pyrazoles $\mathbf{3 c}-\mathbf{f}$ were synthesized in the reaction of tetrazines $\mathbf{1}(\mathrm{Ar}=\mathrm{Ph}$ or 3,5-dimethoxyphenyl) with 2,2-dialkoxy-5,5-dimethyl- $\Delta^{3}$ 1,3,4-oxadiazolines 2 [29], which are the precursor of the dialkoxycarbene (Scheme 3a). Azoalkanes AZc-f $\left(\lambda_{\max } \approx\right.$ $360 \mathrm{~nm}$ with $\varepsilon \approx 100$ ) were obtained by a cycloaddition reaction with cyclopentadienes, and followed by a hydrogenation reaction [30,31]. The synthesis of $\mathbf{A Z g}$ ( $\mathrm{Ar}=3,5$-dimethoxyphenyl, Ar' $=\mathrm{H}$ ) was performed from the corresponding 1,3diketone 4 (Scheme 3b). 2,2-Dimethoxy-1,3-diarylpropane-1,3dione $5 \mathrm{~g}$ was prepared from 1,3-dione 4 ( $\mathrm{R}=3,5$-dimethoxybenzene) according to the method of Tiecco [32]. Pyrazole $\mathbf{3 g}$ was then synthesized by the reaction with hydrazine hydrate. AZg was obtained by the Diels-Alder [4 + 2]-cycloaddition with cyclopentadiene and hydrogenation using $\mathrm{PtO}_{2}$ as a cata-

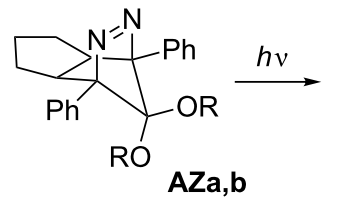

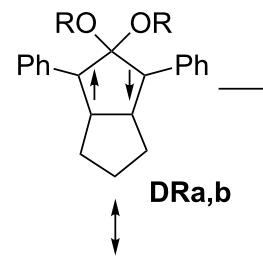<smiles>[R]OC1(O)C([R])C2C3CCCC3C21c1ccccc1</smiles>

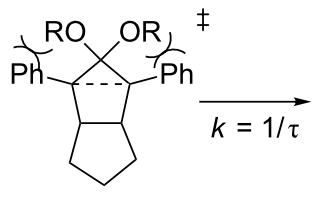

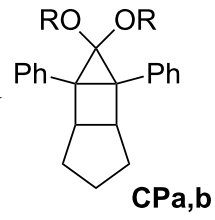

\begin{tabular}{c|cc} 
& $\mathbf{a}$ & $\mathbf{b}$ \\
$\mathrm{OR}$ & $\mathrm{OCH}_{3}$ & $\mathrm{OC}_{10} \mathrm{H}_{21}$ \\
\hline$\tau$ at $293 \mathrm{~K}$ & $292 \mathrm{~ns}$ & $2146 \mathrm{~ns}$
\end{tabular} 


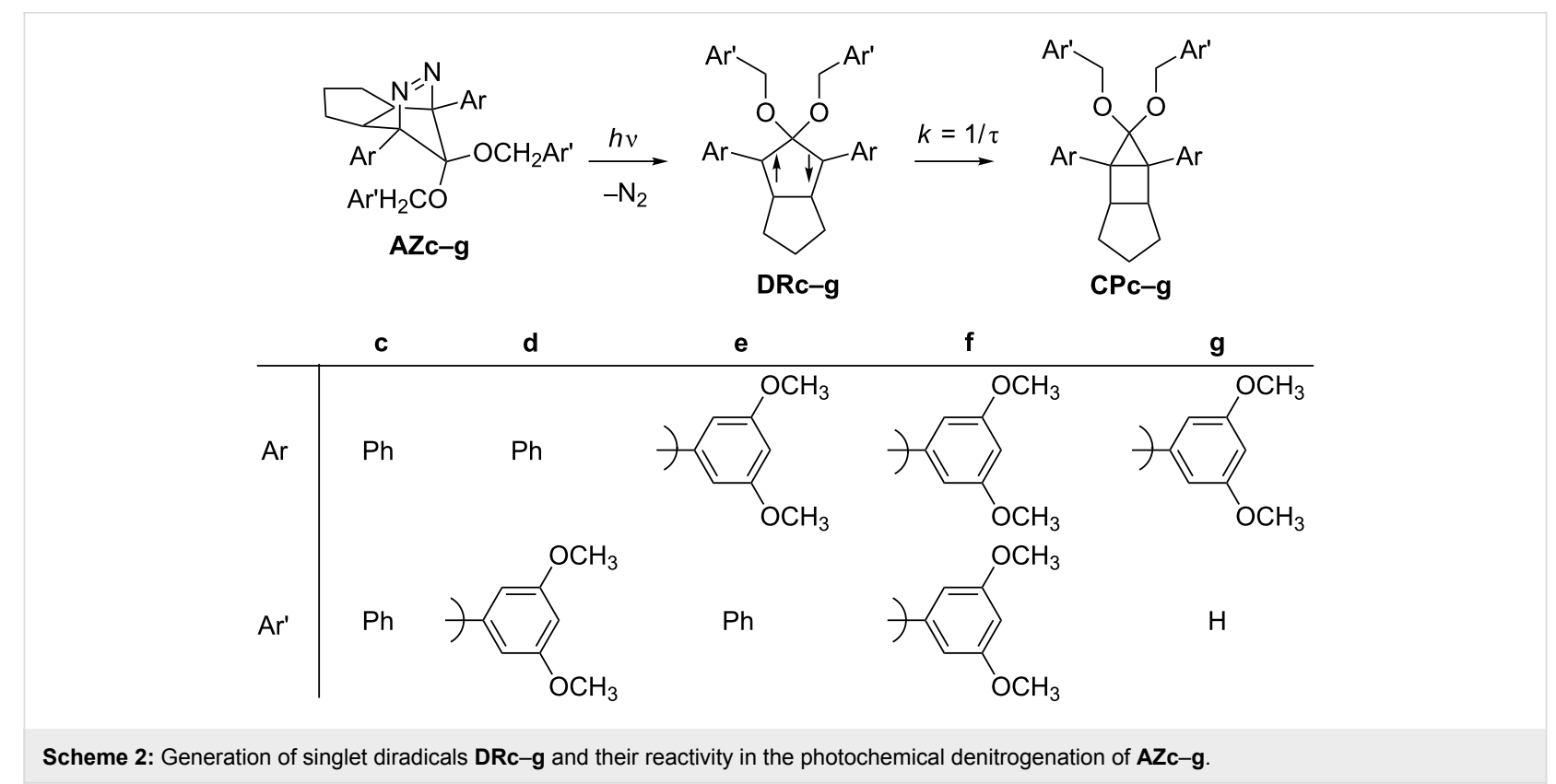

1. cyclopentadiene<smiles>[R20]C1([R2])C([Al])=NN=C1[Te]</smiles>
TFA
$5 \mathrm{~g}$

$\mathrm{Ar}=3,5$-dimethoxybenzyl

Scheme 3: Synthesis of azoalkanes AZc-f and AZg.

lyst. The endo-configured structure of azoalkanes AZc-g was determined by X-ray crystallographic analysis as well as by NOE measurements.

The steady-state photolyses of $\mathbf{A Z c}-\mathbf{g}$ in benzene solution were performed with a Xenon lamp $(500 \mathrm{~W})$ through a Pyrex filter $(h v>300 \mathrm{~nm})$. The ring-closed compounds CPc-g were quantitatively obtained in the denitrogenation reaction (Scheme 2). The quantum yields of the denitrogenation of AZc- - g were determined to be $\approx 0.90$ by comparison with those reported for similar azoalkanes [33]. The quantitative formation of $\mathbf{C P c}-\mathbf{g}$ and the high quantum yield of the denitrogenation process suggest the clean generation of DRc-g in the

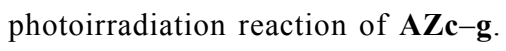

Detection of singlet diradicals DRc-g. The detection of singlet diradicals DRc-g was examined by the photochemical denitrogenation of azoalkanes AZc-g in a glassy matrix of 2-methyltetrahydrofurane (MTHF) at $80 \mathrm{~K},[\mathbf{A Z}] \approx 4 \times 10^{-3} \mathrm{~mol} / \mathrm{L}$, and by the laser flash photolysis experiments of $\mathbf{A Z \mathbf { Z }}-\mathbf{g}$ at room temperature in benzene solution. First of all, the MTHF matrix solution of $\mathbf{A Z}$ was irradiated with a $500 \mathrm{~W}$ Xenon lamp through a monochromator $\left(\lambda_{\mathrm{irr}}=360 \pm 10 \mathrm{~nm}\right)$. A strong absorption band, which corresponds to DRc-g, was observed in the visible region at $80 \mathrm{~K}(570-590 \mathrm{~nm}$, Table 1), as exemplified for the photoirradiation of AZe in Figure 2a. The strong absorption bands are quite similar to those of singlet diradicals DRa,b with $\lambda_{\max }=574 \mathrm{~nm}$ and $572 \mathrm{~nm}[1,28]$, respectively. The assignment of the strong band to the singlet diradical is 
further supported by the following facts: (a) The absorptions obtained on photolysis in a MTHF glass were thermally persistent at $80 \mathrm{~K}$ and resembled that of the transient absorption spectra in solution (for example, DRe, $\lambda_{\max }=590 \mathrm{~nm}$, Figure 2b); (b) the species were ESR-silent in the MTHF-matrix at $80 \mathrm{~K} ;(\mathrm{c})$ the lifetime of the transient was insensitive to the presence of molecular oxygen (decay trace at $580 \mathrm{~nm}$, Figure 2c); and (d) the activation parameters (Table 1) are similar to those for the decay process of DRa, in particular, the high (ca. $10^{12} \mathrm{~s}^{-1}$ ) pre-exponential Arrhenius factors $(\log A)$ are indicative of a spin-allowed reaction to the ring-closed products CPc-g [34].

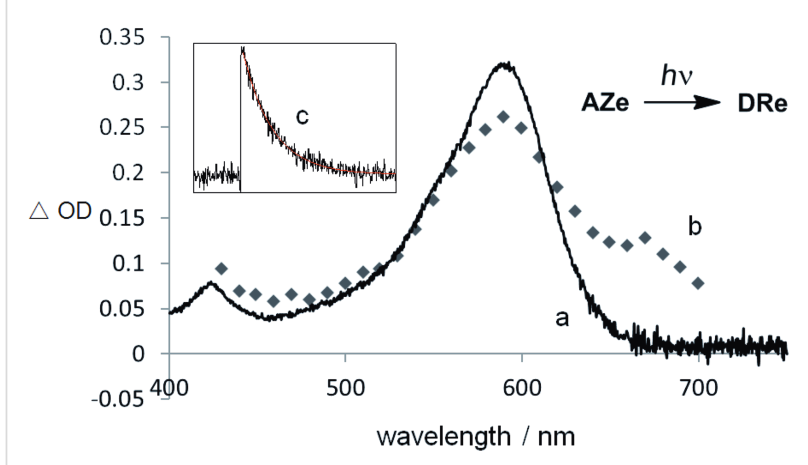

Figure 2: (a) Absorption spectrum of the singlet diradical DRe in a MTHF matrix at $80 \mathrm{~K}$; (b) transient absorption spectrum of AZe measured immediately after the laser pulse $\left(\lambda_{\text {exc }}=355 \mathrm{~nm}\right)$; (c) transient decay trace at $580 \mathrm{~nm}$ and $20^{\circ} \mathrm{C}$

Lifetime of singlet diradicals DRc-g and activation parameters for the ring-closing reaction. The decay traces of the intermediary singlet diradicals DRc-g at 293-333 K were measured in a benzene solution by the laser flash photolysis technique $\left(\lambda_{\text {exc }}=355 \mathrm{~nm}\right)$. The lifetime $(\tau=1 / k)$ was determined by the first-order decay rate constants $(k)$ of DRc-g at
580 nm, e.g., Figure 2c for DRe. As shown in Table 1, the lifetime of the singlet diradical was largely dependent on the substituents Ar and Ar'. The activation parameters, $\Delta H^{\ddagger}, \Delta S^{\ddagger}$, $E_{\mathrm{a}}, \log A$, were determined from the Eyring plots and Arrhenius plots, which were obtained from the temperature-dependent change of the lifetime (Table 1). For comparison, the lifetime of diradical DRa (Table 1, entry 1) was also measured under similar conditions, and determined to be $299 \mathrm{~ns}$ at $293 \mathrm{~K}$. The obtained lifetime was nearly the same as that obtained previously by us (292 ns) [28].

The lifetime of DRc $\left(\mathrm{Ar}=\mathrm{Ar}{ }^{\prime}=\mathrm{Ph}\right)$ was found to be $1305 \mathrm{~ns}$ at $293 \mathrm{~K}$ (Table 1, entry 2), which was ca. 4.5 times longer than the parent DRa. On introduction of a 3,5-dimethoxyphenyl ring at $\mathrm{C}(2)$ position of the 1,3-diradical, i.e., $\mathbf{D R d}\left(\mathrm{Ar}=\mathrm{Ph}, \mathrm{Ar}{ }^{\prime}=\right.$ 3,5-dimethoxyphenyl), a further increase of the lifetime at 293 K was observed to be 1933 ns (Table 1, entry 3). The result clearly indicates that the steric bulkiness plays an important role in increasing the energy barrier for the ring-closing reaction. Indeed, the activation enthalpy $\left(\Delta H^{\star}=36.6 \mathrm{~kJ} \mathrm{~mol}^{-1}\right.$, Table 1 , entry 3) for DRd was found to be higher than that for DRa $\left(\Delta H^{*}=32.7 \mathrm{~kJ} \mathrm{~mol}^{-1}\right.$, Table 1, entry 1). Interestingly, the effect of an aryl group substituent at $\mathrm{C}(1)$ and $\mathrm{C}(3)$ positions on the lifetime was found to be larger than that at $\mathrm{C}(2)$; compare the lifetime of DRe (4001 ns, $\mathrm{Ar}=3$,5-dimethoxyphenyl, $\mathrm{Ar}{ }^{\prime}=\mathrm{Ph}$, Table 1, entry 4) with that of DRd (1933 ns, Table 1, entry 3). When the 3,5-dimethoxyphenyl group was introduced at all of the $\mathrm{C}(1), \mathrm{C}(2)$, and $\mathrm{C}(3)$ positions, the lifetime of the diradical DRf $\left(\Delta G^{*}=42.2 \mathrm{~kJ} \mathrm{~mol}^{-1}\right.$, Table 1 , entry 5$)$ was dramatically increased to $5394 \mathrm{~ns}$ at $293 \mathrm{~K}$. The activation entropy $\left(\Delta S^{\dagger}=\right.$ -27.8 and $-19.4 \mathrm{~J} \mathrm{~mol}^{-1}$, Table 1 , entries 4 and 5) also plays an important role in increasing the lifetime of the singlet species. A much shorter lifetime was found for the diradical DRg ( $\mathrm{Ar}=$ 3,5-dimethoxyphenyl, Ar' $=\mathrm{H}$ ). Thus, the introduction of the bulky substituents is needed at all positions $\mathrm{C}(1)-\mathrm{C}(3)$ of the

Table 1: Lifetimes and activation parameters of singlet diradicals DR.

\begin{tabular}{|c|c|c|c|c|c|c|c|c|}
\hline entry & DR & $\mathrm{T}_{293 \mathrm{~K}} / \mathrm{ns}^{\mathrm{a}}$ & $\operatorname{lnm}^{\mathrm{b}}($ at $80 \mathrm{~K})$ & 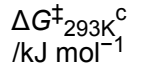 & $\begin{array}{c}\Delta H^{\ddagger c} \\
/ \mathrm{kJ} \mathrm{mol}^{-1}\end{array}$ & $\begin{array}{c}\Delta S^{\ddagger c} \\
/ \mathrm{J} \mathrm{mol}\end{array}$ & $\begin{array}{c}E_{\mathrm{a}}{ }^{\mathrm{c}} \\
/ \mathrm{kJ} \mathrm{mol}^{-1}\end{array}$ & $\log A^{c}$ \\
\hline 1 & DRa & 299 & 573 & $35.1 \pm 0.7$ & $32.7 \pm 0.2$ & $-8.1 \pm 1.2$ & $35.3 \pm 0.2$ & $12.8 \pm 0.1$ \\
\hline 2 & DRc & 1305 & 583 & $39.1 \pm 0.9$ & $33.5 \pm 0.6$ & $-17.9 \pm 1.7$ & $36.2 \pm 0.6$ & $12.3 \pm 0.1$ \\
\hline 3 & DRd & 1933 & 584 & $39.6 \pm 0.6$ & $36.6 \pm 0.1$ & $-10.1 \pm 1.1$ & $39.2 \pm 0.1$ & $12.7 \pm 0.1$ \\
\hline 4 & DRe & 4001 & 592 & $40.9 \pm 0.8$ & $33.3 \pm 0.4$ & $-27.8 \pm 1.3$ & $35.9 \pm 0.4$ & $11.8 \pm 0.1$ \\
\hline 5 & DRf & 5394 & 593 & $42.2 \pm 0.7$ & $36.5 \pm 0.3$ & $-19.4 \pm 1.0$ & $39.1 \pm 0.3$ & $12.2 \pm 0.1$ \\
\hline 6 & DRg & 580 & 583 & $36.7 \pm 0.4$ & $33.0 \pm 0.2$ & $-12.9 \pm 1.0$ & $35.6 \pm 0.2$ & $12.2 \pm 0.1$ \\
\hline
\end{tabular}

axperimental errors are ca. $5 \%$.

bIn MTHF at $80 \mathrm{~K}$.

${ }^{\mathrm{c}}$ Activation parameters were determined by measurements of the lifetime of the singlet diradicals at five different temperatures in a temperature range from 293 to $333 \mathrm{~K}$. 
1,3-diradicals to increase the lifetime. The repulsive steric interactions of the Ar group with the Ar' group are suggested to play important roles in increasing the energy barrier of the reaction from the diradicals to the ring-closed compounds $\mathbf{C P}$. The results clearly indicate that the substituent effect using the sterically bulky group is effective to prolong the lifetime of the singlet diradicals.

\section{Conclusion}

We have succeeded in generating long-lived singlet diradical species DRc-g, $\tau_{293}=580-5394 \mathrm{~ns}$, which were much longerlived species than DRa $\left(\tau_{293}=299 \mathrm{~ns}\right)$. It was found that the lifetimes are largely dependent on the substituent pattern of $\mathrm{Ar}$ and Ar' at the C(1)-C(3) positions of the 1,3-diyls. Thus, both the enthalpy and entropy effect were found to play crucial roles in increasing the lifetime.

\section{Experimental}

All reagents were purchased from commercial sources and were used without additional purification, unless otherwise mentioned. Azoalkanes AZc-g were prepared according to the methods described previously (Scheme 3) and were isolated by silica gel column chromatography and GPC column chromatography. ${ }^{1} \mathrm{H}$ and ${ }^{13} \mathrm{C}$ NMR spectra were reported in parts per million $(\delta)$ by using $\mathrm{CDCl}_{3}$ or $\mathrm{C}_{6} \mathrm{D}_{6}$ as internal standards. Assignments of ${ }^{13} \mathrm{C}$ NMR were carried out by DEPT measurements. IR spectra were recorded with a FTIR spectrometer. UV-vis spectra were taken by a JASCO V-630 spectrophotometer. Mass-spectrometric data were measured by a Mass Spectrometric Thermo Fisher Scientific LTQ Orbitrap XL, performed by the Natural Science Center for Basic Research and Development (NBARD), Hiroshima University.

\section{Preparation of diazenes $\mathbf{A Z \mathbf { Z } - \mathbf { g }}$}

3,6-Diaryl-1,2,4,5-tetrazine 1. 3,6-Diphenyl-1,2,4,5-tetrazine was purchased and directly used. The preparation of 3,6-(3,5-dimethoxyphenyl)-1,2,4,5-tetrazine ( $\mathrm{Ar}=3,5$-dimethoxyphenyl) is as follows: In a $50 \mathrm{~mL}$ round-bottom flask, benzonitrile (3.7 g, $22.7 \mathrm{mmol})$ was dissolved in $10 \mathrm{~mL}$ of absolute ethanol. Hydrazine $(3.6 \mathrm{~mL}, 90 \mathrm{mmol})$ and sulfur $(0.43 \mathrm{~g}, 13.5 \mathrm{mmol})$ were quickly added, and the solution was stirred at room temperature for $1 \mathrm{~h}$ and then heated under reflux for $3 \mathrm{~h}$. The remaining orange cake was solidified further in an ice bath. The solid was vacuum filtered, and washed with cold ethanol $(3 \times 10 \mathrm{~mL})$ giving the crude dihydrotetrazine. The crude orange solid was then placed in a $50 \mathrm{~mL}$ beaker and dissolved in $20 \%$ acetic acid $(15 \mathrm{~mL})$ and $10 \mathrm{~mL}$ ether at room temperature with stirring. An aqueous solution of $10 \% \mathrm{NaNO}_{2}(20 \mathrm{~mL})$ was added to the solution in an ice bath. The immediate purple cloudiness signifies the completion of the reaction, as well as the evolution of brown nitric oxide gas. Vacuum filtration and washing with hot methanol $(3 \times 10 \mathrm{~mL})$ gave the tetrazine as a red solid $(3.07 \mathrm{~g}, 81 \%)$. $\mathrm{mp}: 248-250{ }^{\circ} \mathrm{C}$; IR (neat, $\mathrm{cm}^{-1}$ ): 3022, 2981, 2947, 1611, 1462, 1393, 1221, 1067, 944, 843, 683; ${ }^{1} \mathrm{H}$ NMR $\left(400 \mathrm{MHz}, \mathrm{CDCl}_{3}\right) \delta 3.88(\mathrm{~s}, 6 \mathrm{H}), 6.60(\mathrm{t}, J=$ $2.23 \mathrm{~Hz}, 1 \mathrm{H}), 7.17(\mathrm{~d}, J=2.23 \mathrm{~Hz}, 2 \mathrm{H}) ;{ }^{13} \mathrm{C} \mathrm{NMR}(125 \mathrm{MHz}$, $\left.\mathrm{CDCl}_{3}\right) \delta 55.68\left(\mathrm{q}, \mathrm{OCH}_{3}\right), 105.48(\mathrm{~d}, \mathrm{CH}), 105.90(\mathrm{~d}, \mathrm{CH})$, $133.44(\mathrm{~s}, \mathrm{C}), 161.54\left(\mathrm{~s}, \mathrm{COCH}_{3}\right) ; \operatorname{ESIMS}(\mathrm{m} / \mathrm{z}):[\mathrm{M}+\mathrm{Na}]^{+}$ calcd for $\mathrm{C}_{18} \mathrm{H}_{20} \mathrm{O}_{4} \mathrm{~N}_{4}, 379.13768$; found, 379.13776.

\section{5,5-Dimethyl-2,2-bis(3,5-dimethoxybenzyl)- $\Delta^{3}$-1,3,4-oxa-} diazoline (2f). A solution of (3,5-dimethoxybenzyloxy-carbonyl)hydrazone of acetone $(1.30 \mathrm{~g}, 4.87 \mathrm{mmol})$ in $\mathrm{CH}_{2} \mathrm{Cl}_{2}(5 \mathrm{~mL})$ was added dropwise to a stirred solution of $\mathrm{Pb}(\mathrm{OAc})_{4}(2.59 \mathrm{~g}$, $5.84 \mathrm{mmol}$ ) under nitrogen. The reaction mixture was stirred in an ice bath for $2 \mathrm{~h}$, and then at room temperature for $24 \mathrm{~h}$. After the stirring, the solid was filtered over Celite and the organic layer was washed with $10 \%$ aq $\mathrm{NaHCO}_{3}$. The mixture was filtered again until no precipitate was deposited. The organic phase was concentrated under reduced pressure. The corresponding 3,5-dimethoxybenzyl alcohol (2.46 g, $14.6 \mathrm{mmol})$ and TFA $(0.04 \mathrm{~mL}, 0.49 \mathrm{mmol})$ were then added to the organic mixture. The solution was heated to $40{ }^{\circ} \mathrm{C}$ and stirred for $24 \mathrm{~h}$ before $\mathrm{KOH}$ pellets were added, and stirring was continued for another $3 \mathrm{~h}$. After extracting with $\mathrm{CH}_{2} \mathrm{Cl}_{2}$, washing with brine, and drying by $\mathrm{MgSO}_{4}$, the organic layer was concentrated under reduced pressure. The product was purified by column chromatography (eluent: EtOAc/hexane $=30 / 70, R_{\mathrm{f}}=0.17$ ) to give the product as a yellow liquid $(0.48 \mathrm{~g}, 23 \%)$. IR (neat, $\left.\mathrm{cm}^{-1}\right): 3006$, 2959, 2843, 1750, 1622, 1480, 1386, 1236, 1076, 925, 846, 687; ${ }^{1} \mathrm{H}$ NMR (500 MHz, $\left.\mathrm{CDCl}_{3}\right) \delta 1.49(\mathrm{~s}, 6 \mathrm{H}), 3.67(\mathrm{~s}, 12 \mathrm{H})$, $4.66(\mathrm{q}, J=11.8 \mathrm{~Hz}, 36.78 \mathrm{~Hz}, 4 \mathrm{H}), 6.29$ (t, $J=2.21 \mathrm{~Hz}, 2 \mathrm{H})$, $6.41(\mathrm{~d}, J=2.21 \mathrm{~Hz}, 4 \mathrm{H}) ;{ }^{13} \mathrm{C} \mathrm{NMR}\left(125 \mathrm{MHz}, \mathrm{CDCl}_{3}\right) \delta 24.12$ $\left(\mathrm{q}, \mathrm{CH}_{3}\right), 55.29\left(\mathrm{q}, \mathrm{OCH}_{3}\right), 66.72\left(\mathrm{t}, \mathrm{CH}_{2}\right), 99.94(\mathrm{~d}, \mathrm{CH}, \mathrm{Ar}$ ring), 105.50 (d, $\mathrm{CH}$, Ar ring), $119.63\left(\mathrm{~s}, \mathrm{C}\left(\mathrm{CH}_{3}\right)_{2}\right), 136.71(\mathrm{~s}$, C), $138.97\left(\mathrm{~s}, \mathrm{C}\left(\mathrm{OCH}_{2} \mathrm{Ar}\right)_{2}\right), 160.83\left(\mathrm{~s}, \mathrm{COCH}_{3}\right) ; \operatorname{ESIMS}(\mathrm{m} / \mathrm{z})$ : $[\mathrm{M}+\mathrm{Na}]^{+}$calcd for $\mathrm{C}_{22} \mathrm{H}_{28} \mathrm{O}_{7} \mathrm{~N}_{2} \mathrm{Na}, 455.17887$; found, 455.17899 .

1,3-Bis(3,5-dimethoxyphenyl)propane-1,3-dione (4). 3,5dimethoxyacetophenone (2.1 g, $11.7 \mathrm{mmol}), 3,5$-dimethoxybenzoic acid $(2.75 \mathrm{~g}, 14.04 \mathrm{mmol})$, and $\mathrm{NaH}(0.94 \mathrm{~g}$, $23.4 \mathrm{mmol})$ was dissolved in THF $(20 \mathrm{~mL})$ under $\mathrm{N}_{2}$ atmosphere in a $50 \mathrm{~mL}$ flask. The mixture was heated under reflux $\left(75{ }^{\circ} \mathrm{C}\right.$ ) for $14 \mathrm{~h}$ under a $\mathrm{N}_{2}$ atmosphere, then cooled down to room temperature. The mixture was slowly added to cold $\mathrm{HCl}$. The organic layer was extracted with ether, washed with brine, and dried with anhydrous $\mathrm{MgSO}_{4}$. The solvent was removed by vacuum evaporator. The dry solid was then recrystallized in methanol to give the compound as a yellow crystal $(2.77 \mathrm{~g}$, 69\%). mp: $132{ }^{\circ} \mathrm{C}$; IR (neat, $\mathrm{cm}^{-1}$ ): $3140,3000,2943,1562$, 1466, 1351, 1298, 1158, 1053, 842, 668; ${ }^{1} \mathrm{H}$ NMR (500 MHz, 
$\left.\mathrm{CDCl}_{3}\right) \delta 3.78(\mathrm{~s}, 12 \mathrm{H}), 6.56(\mathrm{t}, J=2.28 \mathrm{~Hz}, 2 \mathrm{H}), 6.65(\mathrm{~d}, J=$ $2.28 \mathrm{~Hz}, 4 \mathrm{H}) ;{ }^{13} \mathrm{C} \mathrm{NMR}\left(125 \mathrm{MHz}, \mathrm{CDCl}_{3}\right) \delta 55.56\left(\mathrm{q}, \mathrm{OCH}_{3}\right)$, $93.56\left(\mathrm{t}, \mathrm{CH}_{2}\right), 104.62(\mathrm{~d}, \mathrm{CH}), 105.05(\mathrm{~d}, \mathrm{CH}), 137.52(\mathrm{~s}, \mathrm{C})$, $160.92\left(\mathrm{~s}, \mathrm{COCH}_{3}\right), 185.47(\mathrm{~s}, \mathrm{OC}=\mathrm{O})$; $\operatorname{ESIMS}(\mathrm{m} / \mathrm{z}):[\mathrm{M}+$ $\mathrm{Na}]^{+}$calcd for $\mathrm{C}_{19} \mathrm{H}_{20} \mathrm{O}_{6} \mathrm{Na}, 367.11521$; found, 367.11456 .

1,3-Bis(3,5-dimethoxyphenyl)-2,2-dimethoxypropane-1,3dione (5). 1,3-Dione 4 (2.76 g, $8 \mathrm{mmol})$ and diphenyl diselenide $(1.25 \mathrm{~g}, 4 \mathrm{mmol})$ were dissolved in methanol $(50 \mathrm{~mL})$, and ammonium persulfate $(3.65 \mathrm{~g}, 16 \mathrm{mmol})$ was added to the mixture. The solution was heated under reflux for $4 \mathrm{~h}$ with stirring under nitrogen. Then the mixture was cooled to room temperature, and slowly added to ice water. The organic compound was extracted by chloroform and purified by silica-gel column chromatography (eluent: EtOAc/hexane $=30 / 70$, $\left.R_{\mathrm{f}}=0.30\right)$ to give the product as a yellow liquid $(2.9 \mathrm{~g}, 90 \%)$. ${ }^{1} \mathrm{H}$ NMR $\left(500 \mathrm{MHz}, \mathrm{CDCl}_{3}\right) \delta 3.41(\mathrm{~s}, 6 \mathrm{H}), 3.77(\mathrm{~s}, 12 \mathrm{H}), 6.59$ $(\mathrm{t}, J=2.44 \mathrm{~Hz}, 2 \mathrm{H}), 7.29(\mathrm{~d}, J=2.44 \mathrm{~Hz}, 4 \mathrm{H}) ;{ }^{13} \mathrm{C}$ NMR $(125$ $\left.\mathrm{MHz}, \mathrm{CDCl}_{3}\right) \delta 50.97\left(\mathrm{q}, \mathrm{C}\left(\mathrm{OCH}_{3}\right)_{2}\right), 55.53\left(\mathrm{q}, \mathrm{OCH}_{3}\right), 103.89$ (s, C), 107.22 (d, CH), 107.34 (d, CH), 135.50 (s, C), 160.66 (s, $\mathrm{COCH}_{3}$ ), 192.47 (s, C=O); IR (neat, $\mathrm{cm}^{-1}$ ): 3027, 2965, 2845, 1691, 1605, 1466, 1429, 1321, 1162, 1070, 1036, 863, 671; ESIMS $(\mathrm{m} / \mathrm{z}):[\mathrm{M}+\mathrm{Na}]^{+}$calcd for $\mathrm{C}_{21} \mathrm{H}_{24} \mathrm{O}_{8} \mathrm{Na}, 427.13634$; found, 427.13602 .

\section{4,4-diaryloxy-3,5-diarylpyrazole (3c-f)}

General Procedure. Oxadiazoline $(1 \mathrm{mmol})$ was dissolved in benzene $(2 \mathrm{~mL})$ in a sealed tube. The mixture was stirred with tetrazine $(1.10 \mathrm{mmol})$ in a sealed tube for $24 \mathrm{~h}$ at $120^{\circ} \mathrm{C}$ under nitrogen. After filtration, the crude was purified by column chromatograph (in ca. $40 \%$ yield).

4,4-Dibenzyloxy-3,5-diphenylpyrazole (3c). Yellow powder (from $\mathrm{MeOH}$ ), $\mathrm{mp}: 150-151{ }^{\circ} \mathrm{C}$; IR (neat, $\mathrm{cm}^{-1}$ ): 3070,3066 , 2948, 2881, 1585, 1557, 1498, 1447, 1391, 1382, 1111, 970, 916, 856, 694; ${ }^{1} \mathrm{H}$ NMR (500 MHz, $\left.\mathrm{CDCl}_{3}\right) \delta 4.21(\mathrm{~s}, 4 \mathrm{H})$, 7.04-7.06 (m, 4H), 7.19-7.20 (m, 6H), 7.50-7.57 (m, 6H), 8.38-8.39 (m, $4 \mathrm{H}) ;{ }^{13} \mathrm{C} \mathrm{NMR}\left(125 \mathrm{MHz}, \mathrm{CDCl}_{3}\right) \delta 66.73(\mathrm{t}$, $\mathrm{CH}_{2}$ ), 115.96 (s, C), 127.74 (d, CH, benzyloxy), 127.95 (d, $\mathrm{CH}$, benzyloxy), 128.13 (d, CH, phenyl), 128.18 (d, CH, benzyloxy), 128.26 (d, CH, phenyl), 129.03 (d, CH, phenyl), 132.47 (s, C, phenyl), 135.45 (s, C, benzyloxy), 167.09 (s, C); HRMS-EI calcd for $\mathrm{C}_{29} \mathrm{H}_{24} \mathrm{~N}_{2} \mathrm{O}_{2}$, 432.1838; found, 432.1842; $R_{\mathrm{f}}=0.40$ $($ EtOAc/hexane $=30 / 70)$.

4,4-Bis(3,5-dimethoxybenzyloxy)-3,5-diphenylpyrazole (3d). Yellow powder (from $\mathrm{MeOH}$ ), mp: $140-141{ }^{\circ} \mathrm{C}$; IR (neat, $\left.\mathrm{cm}^{-1}\right)$ : 3024, 2951, 2845, 1603, 1475, 1456, 1388, 1160, 1118, 1102, 851; ${ }^{1} \mathrm{H}$ NMR (500 MHz, $\left.\mathrm{C}_{6} \mathrm{D}_{6}\right) \delta 3.19(\mathrm{~s}, 12 \mathrm{H}), 4.21(\mathrm{~s}$, $4 \mathrm{H}), 6.28(\mathrm{~d}, J=2.36 \mathrm{~Hz}, 4 \mathrm{H}), 6.42(\mathrm{t}, J=2.36 \mathrm{~Hz}, 2 \mathrm{H}), 7.07$ (d, $J=8.15 \mathrm{~Hz}, 6 \mathrm{H}$, phenyl), 8.68 (m, 4H, phenyl); ${ }^{13} \mathrm{C} \mathrm{NMR}$ $\left(125 \mathrm{MHz}, \mathrm{C}_{6} \mathrm{D}_{6}\right) \delta 55.76\left(\mathrm{q}, \mathrm{OCH}_{3}\right), 67.11\left(\mathrm{t}, \mathrm{CH}_{2}\right), 100.99$ (d, $\mathrm{CH}$, aryl), 106.15 (d, CH, aryl), 116.69 (s, C), 128.35 (d, CH, phenyl), 128.77 (s, C), 129.24 (d, CH, phenyl), 132.30 (d, CH, phenyl), 138.40 (s, C), 161.30 (s, C), 167.29 (s, C); ESIMS $(m / z):[\mathrm{M}+\mathrm{Na}]^{+}$calcd for $\mathrm{C}_{33} \mathrm{H}_{32} \mathrm{O}_{6} \mathrm{~N}_{2} \mathrm{Na}, 575.21526$; found, 575.21387; $R_{\mathrm{f}}=0.27($ EtOAc/hexane $=30 / 70)$.

\section{4,4-Dibenzyloxy-3,5-bis(3,5-dimethoxyphenyl)pyrazole (3e).}

Yellow powder (from $\mathrm{MeOH}$ ), mp: $183-184{ }^{\circ} \mathrm{C}$; IR (neat, $\mathrm{cm}^{-1}$ ): 3025, 2952, 2847, 1605, 1551, 1456, 1426, 1371, 1160, 1117, 849, 670; ${ }^{1} \mathrm{H}$ NMR (500 MHz, $\left.\mathrm{C}_{6} \mathrm{D}_{6}\right) \delta 3.33(\mathrm{~s}, 12 \mathrm{H})$, $4.31(\mathrm{~s}, 2 \mathrm{H}), 6.78(\mathrm{t}, J=2.28 \mathrm{~Hz}, 2 \mathrm{H}), 6.93-7.01(\mathrm{~m}, 10 \mathrm{H})$, $8.02(\mathrm{t}, J=2.28 \mathrm{~Hz}, 4 \mathrm{H}) ;{ }^{13} \mathrm{C} \mathrm{NMR}\left(125 \mathrm{MHz}, \mathrm{C}_{6} \mathrm{D}_{6}\right) \delta 55.06$ (q, $\left.\mathrm{OCH}_{3}\right), 67.02\left(\mathrm{t}, \mathrm{CH}_{2}\right), 105.54(\mathrm{~d}, \mathrm{CH}, \operatorname{aryl}), 106.52(\mathrm{~d}, \mathrm{CH}$, aryl), 116.22 (s, C), 128.59 (d, CH, phenyl), 128.45 (d, CH, phenyl), 128.19 (d, CH, phenyl), 130.47 (s, C, aryl), 136.24 (s, $\mathrm{C}$, phenyl), $161.81\left(\mathrm{~s}, \mathrm{COCH}_{3}\right), 167.53$ (s, C); ESIMS $(\mathrm{m} / \mathrm{z})$ : $[\mathrm{M}+\mathrm{H}]^{+}$calcd for $\mathrm{C}_{33} \mathrm{H}_{33} \mathrm{~N}_{6} \mathrm{O}_{2}, 553.23331$; found, 553.23267; $R_{\mathrm{f}}=0.13($ EtOAc/hexane $=20 / 80)$.

4,4-Bis(3,5-dimethoxybenzyloxy)-3,5-bis(3,5-dimethoxyphenyl)pyrazole (3f). IR (neat, $\mathrm{cm}^{-1}$ ): 3010, 2942, 1605, 1552, 1441, 1371, 1140, 1120, 849; ${ }^{1} \mathrm{H}$ NMR (500 MHz, $\left.\mathrm{CDCl}_{3}\right) \delta$ $3.24(\mathrm{~s}, 12 \mathrm{H}), 3.34(\mathrm{~s}, 12 \mathrm{H}), 4.36(\mathrm{~s}, 6 \mathrm{H}), 6.38(\mathrm{~d}, J=2.36 \mathrm{~Hz}$, $4 \mathrm{H}), 6.43(\mathrm{t}, J=2.36 \mathrm{~Hz}, 2 \mathrm{H}), 6.70(\mathrm{t}, J=2.28 \mathrm{~Hz}, 2 \mathrm{H}), 8.04$ $(\mathrm{d}, J=2.28 \mathrm{~Hz}, 4 \mathrm{H}) ;{ }^{13} \mathrm{C} \mathrm{NMR}\left(125 \mathrm{MHz}, \mathrm{C}_{6} \mathrm{D}_{6}\right) \delta 54.74(\mathrm{q}$, $\left.\mathrm{OCH}_{3}\right), 55.03\left(\mathrm{q}, \mathrm{OCH}_{3}\right), 67.19\left(\mathrm{t}, \mathrm{CH}_{2}\right), 101.16(\mathrm{~d}, \mathrm{CH})$, 105.71 (d, CH), 106.08 (d, CH), 106.28 (d, CH), 116.36 (s, C), 130.46 (s, C), 138.47 (s, C), $161.33\left(\mathrm{~s}, \mathrm{COCH}_{3}\right), 161.77$ (s, $\left.\mathrm{COCH}_{3}\right), 167.58(\mathrm{~s}, \mathrm{C})$; $\operatorname{ESIMS}(\mathrm{m} / \mathrm{z}):[\mathrm{M}+\mathrm{Na}]^{+}$calcd for $\mathrm{C}_{37} \mathrm{H}_{40} \mathrm{O}_{10} \mathrm{~N}_{2} \mathrm{Na}$, 695.25752; found, 695.25775; $R_{\mathrm{f}}=0.17$ $($ EtOAc/hexane $=30 / 70)$.

4,4-Dimethoxy-3,5-bis(3,5-dimethoxyphenyl)pyrazole (3g). To a solution of 1,3-bis(3,5-dimethoxyphenyl)-2,2dimethoxypropane-1,3-dione $(2.8 \mathrm{~g}, 6.92 \mathrm{mmol})$ in chloroform $(10 \mathrm{~mL})$ was added dropwise $\mathrm{NH}_{2} \mathrm{NH}_{2} \cdot \mathrm{H}_{2} \mathrm{O}(0.40 \mathrm{~mL}$, $8.30 \mathrm{mmol})$. The mixture was heated under reflux and kept under stirring for $6 \mathrm{~h}$. The reaction was quenched with $\mathrm{HCl}$. A solution of $10 \% \mathrm{NaHCO}_{3}$ was added to the mixture. After extraction with chloroform, the organic phase was washed with brine, dried with $\mathrm{Na}_{2} \mathrm{SO}_{4}$, concentrated and then purified by column chromatography to give $\mathbf{3 g}$ in $89.6 \%$ yield. $\mathrm{mp}$ : 179-180 ${ }^{\circ} \mathrm{C} ;{ }^{1} \mathrm{H}$ NMR $\left(500 \mathrm{MHz}, \mathrm{CDCl}_{3}\right) \delta 3.04$ (s, 6H), 3.83 $(\mathrm{s}, 12 \mathrm{H}), 6.62(\mathrm{t}, J=2.28 \mathrm{~Hz}, 2 \mathrm{H}), 7.40(\mathrm{~d}, J=2.28 \mathrm{~Hz}, 4 \mathrm{H})$; ${ }^{13} \mathrm{C}$ NMR (125 MHz, $\left.\mathrm{CDCl}_{3}\right) \delta 51.93\left(\mathrm{q}, \mathrm{CH}_{3}\right), 55.52$ (q, $\left.\mathrm{OCH}_{3}\right), 105.21(\mathrm{~d}, \mathrm{CH}),$,105.27 (d, CH), $116.91(\mathrm{~s}, \mathrm{C}), 129.23$ (s, C), $161.00\left(\mathrm{~s}, \mathrm{COCH}_{3}\right), 166.84(\mathrm{~s}, \mathrm{C})$; IR (neat, $\left.\mathrm{cm}^{-1}\right)$ : 3012, 2951, 1597, 1548, 1427, 1375, 1158, 1125, 1062, 980, 844; ESIMS $(m / z)$ : calcd for $\mathrm{C}_{21} \mathrm{H}_{25} \mathrm{~N}_{6} \mathrm{O}_{2}, 401.17071$; found, $401.17041 ; R_{\mathrm{f}}=0.10($ EtOAc/hexane $=20 / 80)$. 
endo-2,3-Diazo-10,10-diaryloxy-1,4diaryltricyclo[5.2.1.0 $0^{5,9}$ ]dec-2-ene (AZc-g)

General procedure. To a solution of cyclopentadiene $(1 \mathrm{~mL})$ and pyrazole ( $2 \mathrm{mmol})$ in $\mathrm{CH}_{2} \mathrm{Cl}_{2}(2 \mathrm{~mL})$ was added dropwise trifluoroacetic acid $(1 \mathrm{mmol})$ in an ice bath under nitrogen. The reaction was traced by TLC analysis. After stirring for about $15 \mathrm{~min}$, the reaction was quenched with $10 \%$ aq $\mathrm{NaHCO}_{3}$ until the $\mathrm{pH}$ of the solution reached 8 . After washing with water and brine, the organic phase was dried with $\mathrm{MgSO}_{4}$, then filtered and concentrated. The $[4+2]$ cycloadduct was dissolved in benzene $(2 \mathrm{~mL})$, and $5 \mathrm{mg}$ of $\mathrm{PtO}_{2}$ was added as a catalyst. The mixture was stirred under a hydrogen atmosphere for $24 \mathrm{~h}$ at room temperature. After stirring, the catalyst was removed by filtration over Celite, and the solvent was evaporated under reduced pressure. The product was purified by column chromatograph to give the product as colorless liquid (ca. $60 \%$ ). The endo configuration was determined by NOE measurements.

endo-2,3-Diazo-10,10-dibenzyloxy-1,4-diphenyltricyclo[5.2.1.0 ${ }^{\mathbf{5}, 9}$ ]dec-2-ene (AZc). IR (neat, $\mathrm{cm}^{-1}$ ): 3037, 2968, 2886, 1739, 1607, 1498, 1456, 1387, 1139, 1085, 1029, 702; UV (MTHF) $\lambda_{\max } 365$ ( $\varepsilon$ 106.7); ${ }^{1} \mathrm{H}$ NMR $\left(500 \mathrm{MHz}, \mathrm{C}_{6} \mathrm{D}_{6}\right) \delta$ $1.20-1.75$ (m, 6H), 3.69 (t, $J=5.13 \mathrm{~Hz}, 2 \mathrm{H}), 4.15(\mathrm{~s}, 2 \mathrm{H}), 4.29$ (s, 2H), 6.90-8.19 (m, 20H, overlapping with $\left.\mathrm{C}_{6} \mathrm{H}_{6}\right) ;{ }^{13} \mathrm{C} \mathrm{NMR}$ (125 MHz, $\left.\mathrm{C}_{6} \mathrm{D}_{6}\right) \delta 25.96\left(\mathrm{t}, \mathrm{CH}_{2}\right.$, cyclopentane), $28.16(\mathrm{t}$, $\mathrm{CH}_{2}$, cyclopentane), 49.27 (d, $\mathrm{CH}$, cyclopentane), 66.16 (t, $\left.\mathrm{COCH}_{2}\right), 66.34\left(\mathrm{t}, \mathrm{OCH}_{2}\right), 94.83(\mathrm{~s}, \mathrm{C}), 119.57(\mathrm{~s}, \mathrm{C}), 126.66$ $(\mathrm{d}, \mathrm{CH}), 126.87(\mathrm{~d}, \mathrm{CH}), 127.33(\mathrm{~d}, \mathrm{CH}), 128.61(\mathrm{~d}, \mathrm{CH})$, 128.71 (d, CH), 129.01 (d, CH), 137.22 (s, C), 138.13 (s, C), 138.19 (s, C); HRMS-EI $(\mathrm{m} / \mathrm{z})$ : calcd for $\mathrm{C}_{34} \mathrm{H}_{32} \mathrm{O}_{2} \mathrm{~N}_{2}$, 500.6301; found, 500.2462. $R_{\mathrm{f}}=0.57(\mathrm{EtOAc} /$ hexane $=20 / 80)$.

endo-2,3-Diazo-10,10-bis(3,5-dimethoxybenzyloxy)-1,4diphenyltricyclo[5.2.1.0 ${ }^{5,9}$ ]dec-2-ene (AZd). IR (neat, $\mathrm{cm}^{-1}$ ): 3022, 2966, 2844, 1751, 1603, 1473, 1326, 1162, 1072, 930, 844, 703; UV (MTHF) $\lambda_{\max } 364$ ( $\varepsilon$ 175.1); ${ }^{1} \mathrm{H}$ NMR $(500 \mathrm{MHz}$, $\left.\mathrm{CDCl}_{3}\right) \delta 1.25-1.66(\mathrm{~m}, 6 \mathrm{H}), 3.68(\mathrm{~s}, 6 \mathrm{H}), 3.70(\mathrm{t}, J=5.33 \mathrm{~Hz}$, $2 \mathrm{H}), 3.75(\mathrm{~s}, 6 \mathrm{H}), 3.89(\mathrm{~s}, 2 \mathrm{H}), 4.12(\mathrm{~s}, 2 \mathrm{H}), 6.07$ (d, $J=2.36$ $\mathrm{Hz}, 2 \mathrm{H}), 6.24$ (t, $J=2.36 \mathrm{~Hz}, 1 \mathrm{H}), 6.30$ (d, $J=2.36 \mathrm{~Hz}, 2 \mathrm{H})$, $6.36(\mathrm{t}, J=2.36 \mathrm{~Hz}, 1 \mathrm{H}), 7.40-8.03(\mathrm{~m}, 10 \mathrm{H}) ;{ }^{13} \mathrm{C} \mathrm{NMR}(125$ $\left.\mathrm{MHz}, \mathrm{C}_{6} \mathrm{D}_{6}\right) \delta 26.21\left(\mathrm{t}, \mathrm{CH}_{2}\right.$, cyclopentane), 28.34 (t, $\mathrm{CH}_{2}$, cyclopentane), 49.42 (d, $\mathrm{CH}$, cyclopentane), $55.69\left(\mathrm{q}, \mathrm{OCH}_{3}\right)$, $55.74\left(\mathrm{q}, \mathrm{OCH}_{3}\right), 66.17\left(\mathrm{t}, \mathrm{COCH}_{2}\right), 95.15$ (s, C), 99.80 (d, $\mathrm{CH}), 100.00$ (d, CH), $104.26(\mathrm{~d}, \mathrm{CH}), 105.04(\mathrm{~d}, \mathrm{CH}), 119.54$ (s, C), 128.55 (d, CH), $128.92(\mathrm{~d}, \mathrm{CH}), 128.96(\mathrm{~d}, \mathrm{CH}), 136.67$ (s, C), 140.41 (s, C), 140.67 (s, C), 161.00 (s, C), 161.28 (s, C); ESIMS $(\mathrm{m} / \mathrm{z})$ : $[\mathrm{M}+\mathrm{H}]^{+}$calcd for $\mathrm{C}_{38} \mathrm{H}_{41} \mathrm{O}_{6} \mathrm{~N}_{2}, 621.29591$; found, 621.29449; $R_{\mathrm{f}}=0.27($ EtOAc/hexane $=20 / 80)$.

endo-2,3-diazo-1,4-bis(3',5'-dimethoxybenzyloxy)-10,10dibenzyloxytricyclo[5.2.1.0 $\left.{ }^{5,9}\right]$ dec-2-ene (AZe). IR (neat, $\left.\mathrm{cm}^{-1}\right): 3014,2972,1600,1461,1450,1357,1157,1069,973$, 856; UV (MTHF) $\lambda_{\max } 365$ ( $\varepsilon$ 184.2); ${ }^{1} \mathrm{H}$ NMR $(500 \mathrm{MHz}$, $\left.\mathrm{C}_{6} \mathrm{D}_{6}\right) \delta 1.20-1.83(\mathrm{~m}, 6 \mathrm{H}), 3.41(\mathrm{~s}, 12 \mathrm{H}), 3.57(\mathrm{t}, J=4.47 \mathrm{~Hz}$, $2 \mathrm{H}), 4.31(\mathrm{~s}, 2 \mathrm{H}), 4.46(\mathrm{~s}, 2 \mathrm{H}), 6.68(\mathrm{t}, J=2.28 \mathrm{~Hz}, 2 \mathrm{H}), 6.95$ $(\mathrm{d}, J=2.28 \mathrm{~Hz}, 4 \mathrm{H}), 7.02-7.57(\mathrm{~m}, 10 \mathrm{H}$, overlapping with $\left.\mathrm{C}_{6} \mathrm{D}_{6}\right) ;{ }^{13} \mathrm{C}$ NMR $\left(125 \mathrm{MHz}, \mathrm{C}_{6} \mathrm{D}_{6}\right) \delta 26.13\left(\mathrm{t}, \mathrm{CH}_{2}\right.$, cyclopentane), 28.19 (t, $\mathrm{CH}_{2}$, cyclopentane), 49.50 (d, CH, cyclopentane), $54.91\left(\mathrm{q}, \mathrm{OCH}_{3}\right), 66.04\left(\mathrm{t}, \mathrm{COCH}_{2}\right), 66.32\left(\mathrm{t}, \mathrm{COCH}_{2}\right)$, 94.96 (s, C), 101.03 (d, CH), $107.11(\mathrm{~d}, \mathrm{CH}), 119.74(\mathrm{~s}, \mathrm{C})$, 127.00 (d, CH), $127.16(\mathrm{~d}, \mathrm{CH}), 127.38(\mathrm{~d}, \mathrm{CH}), 127.72$ (d, $\mathrm{CH}), 128.54$ (d, CH), 128.60 (d, CH), 138.19 (s, C), 138.24 (s, C), $139.58(\mathrm{~s}, \mathrm{C}), 161.62(\mathrm{~s}, \mathrm{C})$; $\operatorname{ESIMS}(\mathrm{m} / \mathrm{z}):[\mathrm{M}+\mathrm{Na}]^{+}$calcd for $\mathrm{C}_{38} \mathrm{H}_{40} \mathrm{O}_{6} \mathrm{~N}_{2} \mathrm{Na}, 643.27786$; found, 643.27802.

endo-2,3-Diazo-1,4-bis(3,5-dimethoxybenzyloxy)-10,10bis(3,5-dimethoxyphenoxy)tricyclo[5.2.1.0 $\left.{ }^{5,9}\right]$ dec-2-ene (AZf). IR (neat, $\mathrm{cm}^{-1}$ ): 3009, 2965, 2842, 1606, 1467, 1430, 1352, 1160, 1070, 1057, 943, 840; UV (MTHF) $\lambda_{\max } 365$ ( $\varepsilon$ 249.6); ${ }^{1} \mathrm{H}$ NMR (500 MHz, $\left.\mathrm{C}_{6} \mathrm{D}_{6}\right) \delta 1.20-1.80(\mathrm{~m}, 6 \mathrm{H}), 3.23$ (s, 6H), $3.32(\mathrm{~s}, 6 \mathrm{H}), 3.44(\mathrm{~s}, 12 \mathrm{H}), 3.60(\mathrm{t}, J=5.37 \mathrm{~Hz}, 2 \mathrm{H})$, $4.38(\mathrm{~s}, 2 \mathrm{H}), 4.56(\mathrm{~s}, 2 \mathrm{H}), 6.33(\mathrm{~d}, J=2.29 \mathrm{~Hz}, 2 \mathrm{H}), 6.40(\mathrm{t}, J=$ $2.29 \mathrm{~Hz}, 1 \mathrm{H}), 6.46(\mathrm{t}, J=2.29 \mathrm{~Hz}, 1 \mathrm{H}) 6.54(\mathrm{~d}, J=2.29 \mathrm{~Hz}$, $2 \mathrm{H}), 6.64(\mathrm{t}, J=2.28 \mathrm{~Hz}, 2 \mathrm{H}), 7.62(\mathrm{~d}, J=2.28 \mathrm{~Hz}, 4 \mathrm{H}) ;{ }^{13} \mathrm{C}$ NMR (125 MHz, $\left.\mathrm{C}_{6} \mathrm{D}_{6}\right) \delta 26.11\left(\mathrm{t}, \mathrm{CH}_{2}\right.$, cyclopentane), 28.16 (t, $\mathrm{CH}_{2}$, cyclopentane), 49.52 (d, CH, cyclopentane), 54.69 (q, $\left.\mathrm{OCH}_{3}\right), 54.81\left(\mathrm{q}, \mathrm{OCH}_{3}\right), 54.91\left(2 \times \mathrm{q}, \mathrm{OCH}_{3}\right), 65.93(\mathrm{t}$, $\left.\mathrm{COCH}_{2}\right), 66.32\left(\mathrm{t}, \mathrm{COCH}_{2}\right), 95.11(\mathrm{~s}, \mathrm{C}), 100.08(\mathrm{~d}, \mathrm{CH})$, 100.32 (d, CH), $100.92(2 \times d, C H), 104.62$ (s, C), 104.70 (s, C), $107.23(2 \times \mathrm{s}, \mathrm{C}), 119.91(\mathrm{~s}, \mathrm{C}), 139.46(2 \times \mathrm{s}, \mathrm{C}), 140.66(\mathrm{~s}, \mathrm{C})$, $140.77(\mathrm{~s}, \mathrm{C}), 161.33(2 \times \mathrm{s}, \mathrm{C}), 161.58(\mathrm{~s}, \mathrm{C}), 161.62(\mathrm{~s}, \mathrm{C})$; ESIMS $(m / z):[\mathrm{M}+\mathrm{Na}]^{+}$calcd for $\mathrm{C}_{42} \mathrm{H}_{48} \mathrm{O}_{10} \mathrm{~N}_{2} \mathrm{Na}$, 763.32012; found, 763.32043 .

endo-2,3-Diazo-1,4-bis(3,5-dimethoxybenzyloxy)-10,10dimethoxytricyclo[5.2.1.0 ${ }^{\mathbf{5}, 9}$ ] dec-2-ene (AZg). IR (neat, $\left.\mathrm{cm}^{-1}\right)$ : 2973, 2846, 1602, 1464, 1359, 1158, 1088, 1022, 942, 848; UV (MTHF) $\lambda_{\max } 364$ ( $\varepsilon$ 169.9); ${ }^{1} \mathrm{H}$ NMR (500 MHz, $\left.\mathrm{C}_{6} \mathrm{D}_{6}\right) \delta 0.9-1.75(\mathrm{~m}, 6 \mathrm{H}), 2.69(\mathrm{~s}, 3 \mathrm{H}), 2.80(\mathrm{~s}, 3 \mathrm{H}), 3.36(\mathrm{t}, J$ $=5.49 \mathrm{~Hz}, 2 \mathrm{H}), 3.42(\mathrm{~s}, 12 \mathrm{H}), 6.64(\mathrm{t}, J=2.28 \mathrm{~Hz}, 2 \mathrm{H}), 7.48(\mathrm{~d}$, $J=2.28 \mathrm{~Hz}, 4 \mathrm{H}) ;{ }^{13} \mathrm{C} \mathrm{NMR}\left(125 \mathrm{MHz}, \mathrm{C}_{6} \mathrm{D}_{6}\right) \delta 26.08\left(\mathrm{t}, \mathrm{CH}_{2}\right.$, cyclopentane), 28.16 (t, $\mathrm{CH}_{2}$, cyclopentane), 49.29 (d, $\mathrm{CH}$, cyclopentane), $51.46\left(\mathrm{q}, \mathrm{OCH}_{3}\right), 51.75\left(\mathrm{q}, \mathrm{OCH}_{3}\right), 51.92(2 \times \mathrm{q}$, $\left.\mathrm{OCH}_{3}\right), 94.65$ (s, C), 100.30 (d, CH), 107.33 (d, CH), 119.76 (s, C), $139.86(\mathrm{~s}, \mathrm{C}), 161.52(\mathrm{~s}, \mathrm{C})$; $\operatorname{ESIMS}(\mathrm{m} / \mathrm{z}):[\mathrm{M}+\mathrm{Na}]^{+}$calcd for $\mathrm{C}_{26} \mathrm{H}_{32} \mathrm{O}_{6} \mathrm{~N}_{2} \mathrm{Na}$, 491.21526; found, 491.21466.

General procedure for photolysis. A sample $(30.0 \mathrm{mg})$ of the diazenes $\mathbf{A Z}$ was dissolved in $1.0 \mathrm{~mL}$ of $\mathrm{C}_{6} \mathrm{D}_{6}$. The photolysis was performed with a $500 \mathrm{~W}$ Xenon-lamp through a Pyrex filter $(h v>300 \mathrm{~nm})$ at room temperature $\left(\mathrm{ca} .20^{\circ} \mathrm{C}\right)$. The photolysate was directly analyzed by NMR spectroscopy $\left({ }^{1} \mathrm{H}: 500 \mathrm{MHz}\right.$, 
${ }^{13} \mathrm{C}: 125 \mathrm{MHz}$ ), which indicated the quantitative formation of the housanes CP. The housanes $\mathbf{C P c}-\mathbf{g}$ were isolated by using silica-gel column chromatography. The spectroscopic data are as follows:

3,3-Dibenzyloxy-2,4-diphenyltricyclo $\left[3.3 .0 .0^{2,4}\right]$ octane (CPc). ${ }^{1} \mathrm{H}$ NMR (500 MHz, $\left.\mathrm{C}_{6} \mathrm{D}_{6}\right) \delta 1.41-1.93$ (m, 6H), 3.19 (d, $J=6.34 \mathrm{~Hz}, 2 \mathrm{H}), 4.31(\mathrm{~s}, 2 \mathrm{H}), 4.92$ (s, 2H), 6.96-7.45 (m, $20 \mathrm{H}$, overlapping with $\left.\mathrm{C}_{6} \mathrm{D}_{6}\right) ;{ }^{13} \mathrm{C}$ NMR $\left(125 \mathrm{MHz}, \mathrm{C}_{6} \mathrm{D}_{6}\right) \delta$ 25.28 ( $\mathrm{t}, \mathrm{CH}_{2}$, cyclopentane), 28.38 ( $\mathrm{t}, \mathrm{CH}_{2}$, cyclopentane), 41.73 (d, $\mathrm{CH}$, cyclopentane), 48.05 (s, C), $67.16\left(\mathrm{t}, \mathrm{COCH}_{2}\right)$, $69.66\left(\mathrm{t}, \mathrm{OCH}_{2}\right), 98.43$ (s, C), $126.57(\mathrm{~d}, \mathrm{CH}), 127.26(\mathrm{~d}, \mathrm{CH})$, $127.40(\mathrm{~d}, \mathrm{CH}), 127.92(\mathrm{~d}, \mathrm{CH}), 128.12(\mathrm{~d}, \mathrm{CH}), 128.35$ (d, $\mathrm{CH}), 128.46(\mathrm{~d}, \mathrm{CH}), 128.68(\mathrm{~d}, \mathrm{CH}), 130.54(\mathrm{~d}, \mathrm{CH}), 135.25$ (s, C, phenyl), 138.59 (s, C, benzyloxy), 138.90 (s, C, benzyloxy); HRMS-EI $\left(\mathrm{m} / \mathrm{z}\right.$ ): calcd for $\mathrm{C}_{34} \mathrm{H}_{32} \mathrm{O}_{2}, 472.2402$; found, 472.2424 .

3,3-Bis(3,5-dimethoxybenzyloxy)-2,4-diphenyltricyclo[3.3.0. $\mathbf{0}^{\mathbf{2}, \mathbf{4}}$ ]octane (CPd). ${ }^{1} \mathrm{H}$ NMR $\left(500 \mathrm{MHz}, \mathrm{CDCl}_{3}\right) \delta$ 1.40-1.92 $(\mathrm{m}, 6 \mathrm{H}), 3.12(\mathrm{~d}, J=6.29 \mathrm{~Hz}, 2 \mathrm{H}), 3.22(\mathrm{~s}, 6 \mathrm{H}), 3.37(\mathrm{~s}, 6 \mathrm{H})$, $4.35(\mathrm{~s}, 2 \mathrm{H}), 4.99(\mathrm{~s}, 2 \mathrm{H}), 6.31(\mathrm{~d}, J=2.36 \mathrm{~Hz}, 2 \mathrm{H}), 6.41(\mathrm{t}, J=$ $2.36 \mathrm{~Hz}, 1 \mathrm{H}), 6.56(\mathrm{~d}, J=2.36 \mathrm{~Hz}, 1 \mathrm{H}), 6.81(\mathrm{~d}, J=2.36 \mathrm{~Hz}$, $2 \mathrm{H}), 7.02-7.46\left(\mathrm{~m}, 10 \mathrm{H}\right.$, overlapping with $\left.\mathrm{C}_{6} \mathrm{D}_{6}\right) ;{ }^{13} \mathrm{C}$ NMR (125 MHz, $\mathrm{C}_{6} \mathrm{D}_{6}$ ) $\delta 25.22$ (t, $\mathrm{CH}_{2}$, cyclopentane), 28.34 (t, $\mathrm{CH}_{2}$, cyclopentane), 41.68 (d, $\mathrm{CH}$, cyclopentane), 48.18 (s, C), $54.68\left(\mathrm{q}, \mathrm{OCH}_{3}\right), 54.89$ (q, $\left.\mathrm{OCH}_{3}\right), 67.07\left(\mathrm{t}, \mathrm{COCH}_{2}\right), 69.78$ (t, $\left.\mathrm{COCH}_{2}\right), 98.46$ (s, C), 100.04 (d, CH), 100.06 (d, CH), 104.91 (d, CH), $105.94(\mathrm{~d}, \mathrm{CH}), 126.48(2 \times \mathrm{d}, \mathrm{CH}$, phenyl), 128.04 $\left(2 \times \mathrm{d}, \mathrm{CH}\right.$, phenyl), $130.51\left(2 \times \mathrm{d}, \mathrm{CH}\right.$, phenyl), $135.22\left(2 \times_{\mathrm{s}}, \mathrm{C}\right.$, phenyl), 140.90 (s, C), 141.30 (s, C), 161.19 (s, $\mathrm{COCH}_{3}$ ), $161.64(\mathrm{~s}, \mathrm{COCH})$; ESIMS $(\mathrm{m} / \mathrm{z}):[\mathrm{M}+\mathrm{Na}]^{+}$calcd for $\mathrm{C}_{38} \mathrm{H}_{41} \mathrm{O}_{6} \mathrm{Na}$, 615.27171; found, 615.27130.

3,3-Bisbenzyloxy-2,4-bis(3,5-dimethoxyphenyl)tricyclo[3.3.0.0 ${ }^{2,4}$ ]octane (CPe). ${ }^{1} \mathrm{H}$ NMR $\left(500 \mathrm{MHz}, \mathrm{C}_{6} \mathrm{D}_{6}\right) \delta$ 1.40-2.02 (m, 6H), 3.05 (d, $J=6.40 \mathrm{~Hz}, 2 \mathrm{H}), 3.29$ (s, 12H), $4.41(\mathrm{~s}, 2 \mathrm{H}), 4.90(\mathrm{~s}, 2 \mathrm{H}), 6.43$ (t, $J=2.28 \mathrm{~Hz}, 2 \mathrm{H}), 6.80(\mathrm{~d}, J=$ $2.28 \mathrm{~Hz}, 4 \mathrm{H}), 6.86-7.34\left(\mathrm{~m}, 10 \mathrm{H}\right.$, overlapping with $\left.\mathrm{C}_{6} \mathrm{D}_{6}\right) ;{ }^{13} \mathrm{C}$ NMR (125 MHz, $\left.\mathrm{C}_{6} \mathrm{D}_{6}\right) \delta 25.44$ ( $\mathrm{t}, \mathrm{CH}_{2}$, cyclopentane), 28.43 (t, $\mathrm{CH}_{2}$, cyclopentane), 41.82 (d, CH, cyclopentane), 48.47 (s, C), $54.78\left(\mathrm{q}, \mathrm{OCH}_{3}\right), 67.44\left(\mathrm{t}, \mathrm{COCH}_{2}\right), 69.51\left(\mathrm{t}, \mathrm{COCH}_{2}\right)$, 98.39 (s, C), $99.22(\mathrm{~d}, \mathrm{CH}), 108.88(\mathrm{~d}, \mathrm{CH}), 127.19(\mathrm{~d}, \mathrm{CH})$, 127.54 (d, CH), 127.80 (d, CH), 128.06 (d, CH), 128.18 (d, $\mathrm{CH}), 128.59$ (d, CH), 137.30 (s, C), 138.50 (s, C, phenyl), 138.81 (s, C, phenyl), 160.97 (s, C); $\operatorname{ESIMS~}(\mathrm{m} / \mathrm{z}):[\mathrm{M}+\mathrm{Na}]^{+}$ calcd for $\mathrm{C}_{38} \mathrm{H}_{40} \mathrm{O}_{6} \mathrm{Na}, 615.27171$; found, 615.27167.

3,3-Bis(3,5-dimethoxybenzyloxy)-2,4-bis(3,5-dimethoxyphenyl)tricyclo[3.3.0.0 ${ }^{\mathbf{2}, \mathbf{4}}$ ]octane (CPf). ${ }^{1} \mathrm{H}$ NMR $(500 \mathrm{MHz}$, $\left.\mathrm{C}_{6} \mathrm{D}_{6}\right) \delta 1.43-2.08(\mathrm{~m}, 6 \mathrm{H}), 3.15(\mathrm{~d}, J=6.17 \mathrm{~Hz}, 2 \mathrm{H}), 3.30(\mathrm{~s}$,
$6 \mathrm{H}), 3.35(\mathrm{~s}, 12 \mathrm{H}), 3.38(\mathrm{~s}, 6 \mathrm{H}), 4.51(\mathrm{~s}, 2 \mathrm{H}), 5.01(\mathrm{~s}, 2 \mathrm{H}), 6.34$ $(\mathrm{d}, J=2.36 \mathrm{~Hz}, 2 \mathrm{H}), 6.41(\mathrm{t}, J=2.36 \mathrm{~Hz}, 1 \mathrm{H}), 6.47(\mathrm{t}, J=2.28$ $\mathrm{Hz}, 2 \mathrm{H}), 6.54(\mathrm{t}, J=2.36 \mathrm{~Hz}, 1 \mathrm{H}), 6.80(\mathrm{~d}, J=2.36 \mathrm{~Hz}, 2 \mathrm{H})$, $6.87(\mathrm{~d}, J=2.28 \mathrm{~Hz}, 4 \mathrm{H}) ;{ }^{13} \mathrm{C}$ NMR $\left(125 \mathrm{MHz}, \mathrm{C}_{6} \mathrm{D}_{6}\right) \delta 25.46$ (t, $\mathrm{CH}_{2}$, cyclopentane), 28.44 ( $\mathrm{t}, \mathrm{CH}_{2}$, cyclopentane), 41.80 (d, $\mathrm{CH}$, cyclopentane), 48.64 (s, C), 54.67 (q, $\left.\mathrm{OCH}_{3}\right), 54.78$ (q, $\left.\mathrm{OCH}_{3}\right), 54.89\left(2 \times \mathrm{q}, \mathrm{OCH}_{3}\right), 67.29\left(\mathrm{t}, \mathrm{COCH}_{2}\right), 69.76(\mathrm{t}$, $\left.\mathrm{COCH}_{2}\right), 98.41(\mathrm{~s}, \mathrm{C}), 99.18(2 \times \mathrm{d}, \mathrm{CH}), 100.12(\mathrm{~d}, \mathrm{CH}), 100.32$ $(\mathrm{d}, \mathrm{CH}), 104.93(\mathrm{~d}, \mathrm{CH}), 105.96(\mathrm{~d}, \mathrm{CH}), 108.89(2 \times \mathrm{d}, \mathrm{CH})$, $137.30(2 \times \mathrm{s}, \mathrm{C}), 140.88(\mathrm{~s}, \mathrm{C}), 141.26(\mathrm{~s}, \mathrm{C}), 160.96(2 \times \mathrm{s}$, $\left.\mathrm{COCH}_{3}\right), 161.187\left(\mathrm{~s}, \mathrm{COCH}_{3}\right), 161.59\left(\mathrm{~s}, \mathrm{COCH}_{3}\right)$; ESIMS $(m / z):[\mathrm{M}+\mathrm{Na}]^{+}$calcd for $\mathrm{C}_{42} \mathrm{H}_{48} \mathrm{O}_{10} \mathrm{Na}, 735.31397$; found, 735.31415 .

3,3-Dimethoxy-2,4-bis( $(3$ ', 5',-dimethoxyphenyl)tricyclo[3.3.0.0 $\left.{ }^{2,4}\right]$ octane (CPg). ${ }^{1} \mathrm{H}$ NMR $\left(500 \mathrm{MHz}, \mathrm{C}_{6} \mathrm{D}_{6}\right) \delta$ $1.43-2.03(\mathrm{~m}, 6 \mathrm{H}), 2.94(\mathrm{~s}, 3 \mathrm{H}), 2.96(\mathrm{~d}, J=6.47 \mathrm{~Hz}, 2 \mathrm{H}), 3.37$ $(\mathrm{s}, 12 \mathrm{H}), 3.48(\mathrm{~s}, 3 \mathrm{H}), 6.51(\mathrm{t}, J=2.28 \mathrm{~Hz}, 2 \mathrm{H}), 6.79(\mathrm{~d}, J=$ $2.28 \mathrm{~Hz}, 4 \mathrm{H}) ;{ }^{13} \mathrm{C} \mathrm{NMR}\left(125 \mathrm{MHz}, \mathrm{C}_{6} \mathrm{D}_{6}\right) \delta 25.49\left(\mathrm{t}, \mathrm{CH}_{2}\right.$, cyclopentane), 28.45 (t, $\mathrm{CH}_{2}$, cyclopentane), 41.83 (d, $\mathrm{CH}$, cyclopentane), 48.13 (s, C), 52.37 (q, $\left.\mathrm{OCH}_{3}\right), 54.01$ (q, $\left.\mathrm{OCH}_{3}\right)$, $54.85\left(2 \times \mathrm{q}, \mathrm{OCH}_{3}\right), 98.61(\mathrm{~s}, \mathrm{C}), 99.05(\mathrm{~d}, \mathrm{CH}), 108.88(\mathrm{~d}$, $\mathrm{CH}), 137.59\left(\mathrm{~s}, \mathrm{COCH}_{3}\right), 161.07(\mathrm{~s}, \mathrm{C})$; $\operatorname{ESIMS}(\mathrm{m} / \mathrm{z}):[\mathrm{M}+$ $\mathrm{Na}]^{+}$calcd for $\mathrm{C}_{26} \mathrm{H}_{32} \mathrm{O}_{6} \mathrm{Na}, 463.20911$; found, 463.20844 .

\section{Supporting Information}

\section{Supporting Information File 1}

NMR spectra of compounds 1-5, AZc-g, and $\mathbf{C P c}-\mathbf{g}$.

[http://www.beilstein-journals.org/bjoc/content/

supplementary/1860-5397-9-106-S1.pdf]

\section{Acknowledgements}

NMR and MS measurements were performed at N-BARD, Hiroshima University. This work was supported by a Grant-inAid for Science Research on Innovative Areas "Stimuli-responsive Chemical Species" (No. 24109008), "pi-Space” (No. 21108516), and No. 19350021 from the Ministry of Education, Culture, Sports, Science and Technology, Japan, and by the Tokuyama Science Foundation.

\section{References}

1. Abe, M.; Ye, J.; Mishima, M. Chem. Soc. Rev. 2012, 41, 3808-3820. doi:10.1039/c2cs00005a

2. Abe, M. Chem. Rev. 2013, in press.

3. De Feyter, S.; Diau, E. W.-G.; Zewail, A. H. Angew. Chem., Int. Ed. 2000, 39, 260-263. doi:10.1002/(SICI)1521-3773(20000103)39:1<260::AID-ANIE260>3.0. CO;2-R 
4. Niecke, E.; Fuchs, A.; Baumeister, F.; Nieger, M.; Schoeller, W. W. Angew. Chem., Int. Ed. Engl. 1995, 34, 555-557. doi:10.1002/anie.199505551

5. Schoeller, W. W.; Niecke, E. Phys. Chem. Chem. Phys. 2012, 14, 2015-2023. doi:10.1039/c1cp23016f

6. Scheschkewitz, D.; Amii, H.; Gornitzka, H.; Schoeller, W. W.; Bourissou, D.; Bertrand, G. Science 2002, 295, 1880-1881. doi:10.1126/science.1068167

7. Cui, C.; Brynda, M.; Olmstead, M. M.; Power, P. P. J. Am. Chem. Soc. 2004, 126, 6510-6511. doi:10.1021/ja0492182

8. Wang, X.; Peng, Y.; Olmstead, M. M.; Fettinger, J. C.; Power, P. P. J. Am. Chem. Soc. 2009, 131, 14164-14165. doi:10.1021/ja906053y

9. Cox, H.; Hitchcock, P. B.; Lappert, M. F.; Pierssens, L. J.-M. Angew. Chem., Int. Ed. 2004, 43, 4500-4504. doi:10.1002/anie.200460039

10. Beweries, T.; Kuzora, R.; Rosenthal, U.; Schulz, A.; Villinger, A. Angew. Chem., Int. Ed. 2011, 50, 8974-8978. doi:10.1002/anie.201103742

11. Takeuchi, K.; Ichinohe, M.; Sekiguchi, A. J. Am. Chem. Soc. 2011, 133, 12478-12481. doi:10.1021/ja2059846

12. Sugiyama, H.; Ito, S.; Yoshifuji, M. Angew. Chem., Int. Ed. 2003, 42, 3802-3804. doi:10.1002/anie.200351727

13. Yoshifuji, M.; Hirano, Y.; Schnakenburg, G.; Streubel, R.; Niecke, E.; Ito, S. Helv. Chim. Acta 2012, 95, 1723-1729. doi:10.1002/hlca.201200442

14. Henke, P.; Pankewitz, T.; Klopper, W.; Breher, F.; Schnöckel, H. Angew. Chem., Int. Ed. 2009, 48, 8141-8145. doi:10.1002/anie.200901754

15. Ma, J.; Ding, Y.; Hattori, K.; Inagaki, S. J. Org. Chem. 2004, 69, 4245-4255. doi:10.1021/jo035687v

16. Abe, M.; Ishihara, C.; Takegami, A. J. Org. Chem. 2004, 69, 7250-7255. doi:10.1021/jo0490447

17. Abe, M.; Kubo, E.; Nozaki, K.; Matsuo, T.; Hayashi, T. Angew. Chem., Int. Ed. 2006, 45, 7828-7831. doi:10.1002/anie.200603287

18. Nakamura, T.; Gagliardi, L.; Abe, M. J. Phys. Org. Chem. 2010, 23, 300-307. doi:10.1002/poc.1643

19. Nakamura, T.; Takegami, A.; Abe, M. J. Org. Chem. 2010, 75, 1956-1960. doi:10.1021/jo902714c

20. Mondal, K. C.; Roesky, H. W.; Schwarzer, M. C.; Frenking, G.; Tkach, I.; Wolf, H.; Kratzert, D.; Herbst-Irmer, R.; Niepötter, B.; Stalke, D. Angew. Chem., Int. Ed. 2013, 52, 1801-1805. doi:10.1002/anie.201204487

21. Xu, J. D.; Hrovat, D. A.; Borden, W. T. J. Am. Chem. Soc. 1994, 116, 5425-5427. doi:10.1021/ja00091a054

22. Adam, W.; Borden, W. T.; Burda, C.; Foster, H.; Heidenfelder, T.; Heubes, M.; Hrovat, D. A.; Kita, F.; Lewis, S. B.; Scheutzow, D.; Wirz, J. J. Am. Chem. Soc. 1998, 120, 593-594. doi:10.1021/ja972977i

23. Abe, M.; Adam, W.; Heidenfelder, T.; Nau, W. M.; Zhang, X. J. Am. Chem. Soc. 2000, 122, 2019-2026. doi:10.1021/ja992507j

24. Abe, M.; Kubo, E.; Nozaki, K.; Matsuo, T.; Hayashi, T. Angew. Chem., Int. Ed. 2012, 51, 11924.

25. Abe, M.; Furunaga, H.; Ma, D.; Gagliardi, L.; Bodwell, G. J. J. Org. Chem. 2012, 77, 7612-7619. doi:10.1021/jo3016105

26. Nakagaki, T.; Sakai, T.; Mizuta, T.; Fujiwara, Y.; Abe, M. Chem.-Eur. J. 2013, in press. doi:10.1002/chem.201300038

27. Schoeller, W. W.; Rozhenko, A.; Bourissou, D.; Bertrand, G. Chem.-Eur. J. 2003, 9, 3611-3617. doi:10.1002/chem.200204508
28. Abe, M.; Adam, W.; Hara, M.; Hattori, M.; Majima, T.; Nojima, M.; Tachibana, K.; Tojo, S. J. Am. Chem. Soc. 2002, 124, 6540-6541. doi:10.1021/ja026301।

29. Lu, X.; Reid, D. L.; Warkentin, J. Can. J. Chem. 2001, 79, 319-327.

30. Beck, K.; Hünig, S. Chem. Ber. 1987, 120, 477-483. doi:10.1002/cber.19871200406

31. Adam, W.; Heidenfelder, T.; Sahin, C. Synthesis 1995, 1163-1170. doi:10.1055/s-1995-4072

32. Tiecco, M.; Testaferri, L.; Tingoli, M.; Bartoli, D.; Marini, F. J. Org. Chem. 1991, 56, 5207-5210. doi:10.1021/jo00017a039

33. Clark, W. D. K.; Steel, C. J. Am. Chem. Soc. 1971, 93, 6347-6355. doi:10.1021/ja00753a001

34. Johnston, L. J.; Scaiano, J. C. Chem. Rev. 1989, 89, 521-547. doi:10.1021/cr00093a004

\section{License and Terms}

This is an Open Access article under the terms of the Creative Commons Attribution License

(http://creativecommons.org/licenses/by/2.0), which permits unrestricted use, distribution, and reproduction in any medium, provided the original work is properly cited.

The license is subject to the Beilstein Journal of Organic Chemistry terms and conditions: (http://www.beilstein-journals.org/bjoc)

The definitive version of this article is the electronic one which can be found at: doi:10.3762/bjoc. 9.106 